\title{
Metabolic syndrome but not genetic polymorphisms known to induce NAFLD predicts increased total mortality in subjects with NAFLD (OPERA Study)
}

Aki J. Käräjämäki ${ }^{1,2}$, Janne Hukkanen ${ }^{2}$, Heikki Kauma ${ }^{2}$, Y. Antero Kesäniemi ${ }^{2}$ and Olavi Ukkola $^{2}$

1.) Department of Gastroenterology, Vaasa Central Hospital, Vaasa, Finland

Postal address: Hietalahdenkatu 2-4, 65130 Vaasa, Finland

2.) Research Unit of Internal Medicine, Medical Research Center Oulu, Oulu University Hospital, and University of Oulu, Oulu, Finland

Postal address: PL10, 90029 OYS, Finland

Funding details: This work was supported by the Jussi Lalli's and Eva Mariapori-Lalli's

Foundation; the Medical Foundation of Vaasa, Vaasa, Finland; and the State Research Funding of Vaasa Hospital District.

Word Count: 5,531 (included all but the title page and supplementations)

Corresponding author: Aki Juhani Käräjämäki

Contact details for correspondence: Vaasa Central Hospital, Department of Gastroenterology, Hietalahdenkatu 2-4 65130 Vaasa, Finland. Tel: +358 6213 1111. Fax: +35862132638.

aki.karajamaki@vshp.fi

other e-mails: janne.hukkanen@oulu.fi, heikki.kauma@oulu.fi, antero.kesaniemi@oulu.fi, olavi.ukkola@oulu.fi 


\section{Abstract}

Metabolic syndrome (MetS) and genetic polymorphisms PNPLA3 rs738409, TM6SF2 rs58542926 and MBOAT7 rs641738 are known inductors of non-alcoholic fatty liver disease (NAFLD). However, knowledge about how these affect the mortality of subjects with NAFLD is scarce. Therefore, we investigated the impact of MetS, PNPLA3 rs738409, TM6SF2 rs58542926 and MBOAT7 rs641738 on overall and cardiovascular disease (CVD) specific mortality among subjects with or without NAFLD. NAFLD diagnosis was based on liver ultrasound at the baseline. After this and other comprehensive examinations, 958 middle-aged Finns, 249 with NAFLD, were followed for 21 years. The mortality data was gathered from the National Death Registry. After multiple adjustments, the NAFLD individuals with MetS had increased risk of overall mortality as compared to the NAFLD subjects without MetS (2.054 (1.011-4.173, $\mathrm{p}=0.046))$. However, PNPLA3 rs738409 $(1.049(0.650-1.692, \mathrm{p}=0.844))$, TM6SF2 rs58542926 $(0.721(0.369-1.411, \mathrm{p}=0.340))$ or MBOAT7 rs641738 (0.885 (0.543-1.439, p=0.621)) did not affect the overall mortality. MetS was also a marker of increased risk of CVD mortality ( $15 \%$ vs. $2 \%, p=0.013)$ while genetic polymorphisms did not affect CVD mortality. In conclusion, MetS, but not the gene polymorphisms studied, predicts increased overall and CVD-specific mortality among NAFLD subjects.

\section{Key words:}

non-alcoholic fatty liver disease, cardiovascular disease, mortality, metabolic syndrome, PNPLA3, TM6SF2, MBOAT7 


\section{Introduction}

Non-alcoholic fatty liver disease (NAFLD) is defined as accumulation of hepatic fat exceeding $5 \%$ of liver weight without excess alcohol drinking or other secondary causes [1]. With an estimated global prevalence of about 25\% [2] it is one of the leading causes of liver injury worldwide [1-3]. NAFLD is a continuum covering simple hepatosteatosis and the more progressive forms, nonalcoholic steatohepatitis (NASH) and fibrosis, predisposing to liver cirrhosis and hepatocellular carcinoma [1]. NAFLD is also a risk factor for extrahepatic complications, such as type 2 diabetes (T2D), cardiovascular diseases (CVDs) and atrial fibrillation [1,4,5]. It has been estimated that only about $9 \%$ of biopsy-verified NAFLD subjects will die of hepatic reasons and up to about $40 \%$ due to CVDs $[6,7]$.

Several environmental and genetic factors modify the nature of NAFLD [8]. The most studied genetic variants known to affect the risk of NALFD and its progression are the rs738409 variant of Patatin-like phospholipase domain-containing 3 gene (PNPLA3), the Transmembrane 6 superfamily member 2 (TM6SF2) rs58542926, and the Membrane-bound O-acyltransferase domain containing 7 (MBOAT7) rs641738 [9-12]. The PNPLA3 rs738409 loses the normal wild-type gene function of hydrolytic activity on triglycerides and glycerolipids, thus exposing to steatosis, NASH and liver fibrosis [12-17]. Although fibrosis is associated with increased risk of all-cause mortality in NAFLD patients [18], PNPLA3 rs738409 did not affect the mortality of subjects with hepatosteatosis and was associated with reduced mortality in female subjects without hepatosteatosis [19]. TM6SF2 is disturbed by the rs58542926 variant, making it more unstable, affecting its function in lipid metabolism and resulting in intrahepatic fat accumulation [16,20,21], and possibly even more progressive NAFLD stages [11,17]. The MBOAT7 rs641738 variant is known to reduce the expression of the transferase which alters the acyl remodeling of 
phosphatidylinositol in the liver, leading to association with all NAFLD spectrum stages [9], or at least liver fibrosis [16].

The metabolic syndrome (MetS), a cluster of CVD and T2D risk factors including impaired fasting glucose, hypertension, dyslipidemia and central obesity, has also been indicated as a risk factor in NAFLD patients based on two studies. According to the study of Younossi et al. [22] in NAFLD patients, MetS increased the risk of overall, liver- and CVD-specific mortality compared to those without MetS. Similar results were reported for CVD events and new-onset T2D by our group [23]. To the best of our knowledge, the study of Younossi et al. [22] is the only one showing the effect of MetS on the total mortality of NAFLD subjects, and only the effect of PNPLA3 rs738409 variant on mortality has been reported [19] while the impact of other gene variants is unknown. Therefore, we investigated the impact of these gene variants and MetS on overall and CVD mortality in a prospective middle-aged cohort in the Oulu Project of Elucidating the Risk of Atherosclerosis (OPERA) study (n=958), with a mean follow-up time of 21.0 years. 


\section{Materials and Methods}

The OPERA study was originally launched to study the risk factors of atherosclerotic diseases [24]. A total of 300 men and 300 women aged 40-59 years and randomly selected from the Register of the Social Insurance Institute for the reimbursement of hypertension medication were invited to the study (original study group: 'hypertensives'). After randomization of subjects from the National Health Register (including all inhabitants), their 1:1 age- and sex-matched controls without known hypertension were also invited (original study group: 'controls'). Thus, 1,200 subjects were invited to the study. The invitation was accepted by 1,045 subjects ( $87.1 \%$ ) including 520 men (261 from the hypertension group and 259 from the control group) and 525 women (258 from the hypertension group and 267 from the control group) [24].

At the time of enrollment in 1990-1993, comprehensive laboratory tests after an overnight fast, standardized health questionnaires and clinical examinations, including the assessment of hepatic steatosis by liver-kidney contrast on ultrasonography [25] by an experienced radiologist, were performed at the research laboratory of the Department of Internal Medicine, University of Oulu. MetS was defined by the criteria of the International Diabetes Federation, where abdominal obesity has a central role [26]. Homeostasis model assessment (HOMA-IR), a surrogate for insulin resistance, was calculated by the formula: HOMA-IR $=\mathrm{fS}-\mathrm{insulin}(\mathrm{mU} / \mathrm{L}) \times \mathrm{fP}$-glucose $(\mathrm{mmol} / \mathrm{L}) /$ 22.5 [27]. Systolic and diastolic blood pressure was measured from the right arm in a sitting position after an overnight fast and after 10 to 15 minutes' rest using an automatic oscillometric blood pressure recorder (Dinamap, Critikon Ltd, Tampa, FL, USA). Three measurements were made at one-minute intervals, and the means of the last two were reported. 
Subjects with excess alcohol drinking, i.e. $\geq 210 \mathrm{~g}$ a week in men or $\geq 140 \mathrm{~g}$ a week in women [1], ( $n=63$ in men and $n=13$ in women) or missing hepatic steatosis data $(n=17$, of which 11 without excess alcohol drinking) were excluded from the present study. Due to the very low prevalence of hepatitis B and C in Finland, the presence of these viruses was not examined which is an established practice in the Finnish NAFLD studies [2]. Thus, the final number of study participants was 958. PNPLA3 rs738409, TM6SF2 rs58542926, and MBOAT7 rs641738 were successfully genotyped for 948 subjects, 937 subjects and 935 subjects, respectively. The subjects were subgrouped to carriers of the risk allele (heterozygous or homozygous) or non-carriers of the risk allele (homozygous). In the total cohort, there were 249 subjects $(26.0 \%)$ with NAFLD.

Mortality data was acquired from the National Death Registry. CVD-related deaths were defined as coronary artery disease (CAD) or stroke (subarachnoidal bleeding excluded) as a cause of death. CAD included I20-I25, I46, R96, R98 [ICD-10]/410-414, 798 (not 7980A) [ICD-8/9] as the underlying cause of death or immediate cause of death and I21 or I22 [ICD-10]/410 [ICD-8/9] as first to third contributing cause of death. Stroke included I61, I63 (not I636), I64 [ICD-10]/431, 4330A, 4331A, 4339A, 4340A, 4341A, 4349A, 436 [ICD-9]/431 (except 43101, 43191) 433, 434, 436 [ICD-8] as the main diagnosis (symptom or cause), as the first or second side diagnosis (symptom or cause), as the third side diagnosis (ICD-8/9 only), as an underlying cause of death or immediate cause of death, or as a first to third contributing cause of death.

The study subjects gave written informed consent for the use of their clinical records. The Ethics Committee of the Northern Ostrobothnia Hospital District (Oulu, Finland) approved the study (48/2009). 


\section{Genotyping}

DNA was extracted from human nucleated cells from frozen plasma using high-salt method. All single nucleotide polymorphism analyses (PNPLA3 rs738409, TM6SF2 rs58542926 and MBOAT7 rs641738) were performed by TaqMan assays (Life Technologies, Carlsbad, CA, USA).

\section{Statistics}

Statistical analyses were performed by using IBM SPSS Statistics for Windows version 24 (Armonk, NY, USA) and GraphPad Prism, version 7.0 (GraphPad Software Inc., CA, USA). ChiSquare test was used for categorical variables and analysis of variance (ANOVA) for continuous variables for the statistical significance of differences. The Cox hazards model was used for the predictive value for overall mortality and Chi-Square for the statistical significances of differences in CVD-specific mortality. The p-value $<0.05$ was considered statistically significant. 


\section{Results}

In the total cohort, MetS was present in 350 (37\%) individuals, including $186(53 \%)$ subjects with NAFLD, whereas there were 608 (63\%) subjects without MetS, $63(10 \%)$ of them with NAFLD ( $\mathrm{p}<0.001)$. The prevalence of PNPLA3 rs738409 ( $\mathrm{p}=0.025)$, TM6SF2 rs58542926 $(\mathrm{p}=0.002)$ and MBOAT7 rs641738 ( $\mathrm{p}=0.044)$ was greater among NAFLD subjects than among subjects without NAFLD (Table 1).

The baseline characteristics in subjects by MetS and NAFLD status are depicted in Table 2.

In the total cohort, there were $191(55 \%)$ men and 79 (23\%) diabetic subjects among individuals with MetS, whereas among those without MetS, the number of men was 259 (43\%) and that of diabetics was $18(3 \%)(\mathrm{p}<0.001$ for both). The subjects with MetS had higher body mass index (BMI), systolic and diastolic blood pressure, alanine aminotransferase (ALT), gammaglutamyltransferase (GGT), left ventricular mass index (LVMI), low-density lipoprotein (LDL) cholesterol, triglycerides and HOMA-IR but lower high-density lipoprotein (HDL) cholesterol than subjects without MetS ( $\mathrm{p}=0.001$ for LDL cholesterol; for the others, $\mathrm{p}<0.001$ ). Supplementary Table 1 shows the counts and the statistics for these variables.

The main baseline characteristics of the study participants by the presence or absence of each gene polymorphisms and with or without NAFLD are provided in Supplementary Table 2 and 3, respectively. As the tables show, the subjects with NAFLD and with PNPLA3 rs738409 had lower BMI than NAFLD subjects without this gene variant ( $\mathrm{p}=0.027)$. Moreover, GGT was higher among MBOAT rs641738 carriers as compared to the MBOAT rs641738 non-carriers in the NAFLD group ( $\mathrm{p}=0.019)$. In the non-NAFLD group, PNPLA3 rs738409 tended to imply lower systolic blood pressure $(\mathrm{p}=0.033)$ but higher HDL cholesterol $(\mathrm{p}=0.033)$. 
In the total cohort at baseline, there were no statistically significant differences in the variables in PNPLA3 rs738409 carriers as compared to non-carriers, while BMI was higher $(28.6 \mathrm{~kg} / \mathrm{m} 2$ vs. $27.6 \mathrm{~kg} / \mathrm{m} 2, \mathrm{p}=0.032)$ and $\mathrm{LDL}$ cholesterol lower $(3.3 \mathrm{mmol} / \mathrm{L}$ vs. $3.6 \mathrm{mmol} / \mathrm{L}, \mathrm{p}=0.014)$ in the carriers of TM6SF2 rs58542926 than in those without this risk allele, and the presence of MBOAT7 rs641738 was associated with higher ALT and GGT (for ALT 32U/L vs. 29U/L, p=0.021; for GGT 45U/L vs. 37U/L, p=0.021).

Fig. 1 shows that the subjects with MetS had increased risk for total mortality as compared to the subjects without MetS irrespective of whether NAFLD was present or not. The statistical significance of the differences remained in all three subgroups even after multiple corrections (age, BMI, gender, smoking, original OPERA study group) in the Cox hazards model (the corrected pvalues for subjects with NAFLD, subjects without NAFLD and both groups combined were $\mathrm{p}=0.046, \mathrm{p}=0.027$ and $\mathrm{p}=0.001$, respectively). Notably, the presence of NAFLD did not affect the death rates as compared to the absence of NAFLD ( $\mathrm{p}=0.326$ in subjects with MetS and $\mathrm{p}=0.955$ in subjects without MetS).

The overall mortality among the carriers of PNPLA3 rs738409, TM6SF2 rs58542926 or MBOAT7 rs641738 as compared to the non-carriers of these gene variants was not statistically significantly different for any of the gene variants (Table 3).

The Hazards Ratios for the risk of overall death by the number of gene polymorphisms are shown in Fig. 2. As the figure shows, gene polymorphisms, however prevalent, did not increase the risk of death. Rather, the gene polymorphisms could be seen as offering some protection against all-cause mortality, although statistical significance, even after multiple adjustments (age, sex, BMI, original study group and smoking), was gained only in total cohort $(n=933)$ among those with one risk gene polymorphism ( $\mathrm{p}=0.039)$. When the study participants were re-grouped to those without any genetic polymorphism $(n=167)$ and those with $1-3$ gene polymorphisms $(n=766)$, the latter group was 
protected from overall mortality $(0.677$, CI95\% 0.488-0.940, $\mathrm{p}=0.020)$, but after multiple adjustments (see above), the protection attenuated and the statistical significant of differences was lost $(0.723$, CI95\% 0.520-1.005, $\mathrm{p}=0.054)$. This was also the result when comparing those with one or two gene polymorphisms to the non-carriers ( $\mathrm{p}=0.025$; after multiple adjustments, $\mathrm{p}=0.069$ ). The categorical re-grouping (individuals having 1-3 gene polymorphisms vs. individuals who did not have any polymorphism) showed non-significant differences within the NAFLD group $(\mathrm{p}=0.105)$ or non-NAFLD group ( $\mathrm{p}=0.090$; other data not shown).

The CVD-specific death rates did not significantly depend on PNPLA3 rs738409 or MBOAT7 rs641738 status (Fig. 3). There was a numerical difference in CVD-specific death rates in subjects with and without TM6SF2 rs58542926 alleles, indicating protective effect of variant genotype, but the difference did not reach statistical significance. However, as in the case of overall mortality, MetS at baseline was a marker of increased risk of CVD death during the follow-up. The same results are also provided in Supplementary Table 4 as numerical data. 


\section{Discussion}

The present study shows that the presence of MetS predicts higher risk of CVD mortality and overall mortality in subjects with NAFLD as well as in subjects without NAFLD as compared to subjects without MetS. However, although PNPLA3 rs738409, TM6SF2 rs58542926 and MBOAT7 rs641738 are associated with increased prevalence of NAFLD [9-12,28], the present study shows that these gene variants do not predict increased overall mortality among middle-aged subjects with or without NAFLD in a long-term follow-up.

Despite the increased hepatic fat accumulation, PNPLA3 rs738409 and TM6SF2 rs58542926 are not known to be associated with insulin resistance due to the distinct nature of the accumulated lipid content [28-30]. The intrahepatic lipid composition with PNPLA3 rs738409 is predominantly shown to consist of polyunsaturated triacylglycerols and not metabolically harmful ceramides or diacylglycerols, which along with saturated or monounsaturated triacylglycerols and fatty acids are abundant in obesity-related NAFLD [29,30]. Likewise, TM6SF2 rs58542926 enriches the hepatic lipidome with triglycerides, cholesteryl-esters and polyunsaturated fatty acids, but diminishes its phosphatidylcholine levels [31]. Neutral lipids such as triglycerides and esters do not induce insulin resistance [32], and polyunsaturated fatty acids are also considered protective against liver injury and CVDs [33,34]. The mechanism how MBOAT7 rs641738 alters the hepatic lipidome is not yet well-elucidated, but according to one report, it only alters the composition of liver phosphatidylinositols [35] which regulate cell membranes and signal transduction mechanisms [35,36]. Even though there are divergent reports about the association between MBOAT7 rs641738 and insulin resistance $[9,37]$, the present study may suggest that MBOAT rs641738 does not induce insulin resistance, based on unaffected HOMA-IR and diabetes prevalence at baseline. It is also of note that none of these gene variants are related to obesity-related adipose tissue inflammation, 
which also has a central role in the development of insulin resistance [28,38]. Indeed, obesityrelated NAFLD and insulin resistance are tightly and bidirectionally associated [39]. While obesityrelated NAFLD is also an epiphenomenon of the fat accumulation of other ectopic sites, such as the heart [40], which is also a risk factor for heart-associated mortality [41,42], ectopic fat accumulation has not been reported in genetic NAFLD. Furthermore, the potent role of dysbiotic gut microbiota in obese NAFLD subjects $[43,44]$ on insulin resistance induction $[45,46]$ should not be ignored.

A convincing report with a large cohort showed that PNPLA3 rs738409 and - more clearly TM6SF2 rs58542926 conferred some protection against CAD, whereas MBOAT7 rs641738 had a neutral effect on it [47]. Other studies have also reported similar findings for TM6SF2 rs58542926 $[10,48]$, whereas contradictory results have been presented about the association between PNPLA3 rs738409 and atherosclerosis [49-51]. Worth mentioning is also the Copenhagen Study, consisting a large cohort of the Danish general population, which showed no association between PNPLA3 rs738409 or TM6SF2 rs58542926 and CAD [52]. Although MBOAT7 rs641738 is shown to increase not only the risk of NAFLD but also its severity [35], there are no prior reports of how it affects overall, CVD- or liver-specific mortality. To our knowledge, this is also the first report of the neutral effect of MBOAT7 rs641738 on overall and CVD-specific mortality.

The core of all NAFLD management is individual risk stratification: those at the greatest risk of NAFLD complications need to be aggressively treated while others can be offered guidance on how to avoid future risk accumulation [53]. The present study suggests that the three above-mentioned gene polymorphisms do not predict increased overall mortality in a long-term follow-up among middle-aged individuals. The individuals with genetic predisposition to NAFLD may be considered to have a disease constrained to the liver without increased risk of CVDs or metabolic abnormalities $[16,28]$. The present study is in line with the earlier reports with respect to the role of MetS in deteriorating the prognosis in NAFLD $[22,23]$. Thus, the control of cardiometabolic risk factors 
remains a cornerstone of NAFLD management. Indeed, a recently published cohort study of 18 million Europeans demonstrated that after adjustments for traditional CVD risk factors, NAFLD is not associated with an increased risk of CVDs [54].

We recognize that as a post-hoc study our study may in some parts lack sufficient power to show statistical significance of difference between the groups. For instance, with a larger number of study participants, TM6SF2 rs58542926 might have been shown to protect against CVD-related deaths, as suggested by some earlier studies $[48,55]$, or the protective trend in overall mortality by the number of gene polymorphisms might have become statistically significant. In addition, the cohort included a number of hypertensive individuals. However, the prevalence of hypertension among the study participants $(51 \%)$ was similar to the hypertension prevalence in Finnish community-based studies in the 1990s [56]. Thus, the OPERA cohort can be considered to be quite close to a community-based cohort. Finally, although ultrasound is often used as the first-line method in NAFLD assessment in the clinical practice, it is relatively insensitive and provides only qualitative assessment that does not allow a reliable detection of fibrosis and cirrhosis [1,57].

In summary, our study shows that metabolic syndrome, but not PNPLA3 rs738409, TM6SF2 rs58542926 and MBOAT7 rs641738, increases the risk of overall and cardiovascular-specific mortality among middle-aged individuals irrespective of the presence of NAFLD. However, more studies with larger study cohorts are needed to confirm the findings. 


\section{Acknowledgements}

The authors wish to thank Markku Päivänsalo, $\mathrm{MD}, \mathrm{PhD}$, for excellent liver ultrasound examinations and the laboratory staff and research nurses at the Clinical Research Center, Oulu University Hospital. In particular, Ms. Saija Kortetjärvi is appreciated for the able accomplishment of genotyping.

The present study was granted by Jussi Lalli's and Eva Mariapori-Lalli's Foundation; the Medical Foundation of Vaasa, Vaasa, Finland; and the State Research Funding of Vaasa Hospital District. All these non-profit organizations are warmly acknowledged. 
Disclosure statement

The authors report no conflicts of interest. 


\begin{tabular}{|l|l|l|l|l|}
\hline & NAFLD+ & NAFLD- & Total cohort & p-value \\
PNPLA3 & $104 / 245,42 \%$ & $269 / 703,38 \%$ & $373 / 948,39 \%$ & 0.025 \\
rs738409 & $(8 \%)$ & $(4 \%)$ & $(5 \%)$ & \\
\hline $\begin{array}{l}\text { TM6mozygotes) } \\
\text { rs58542926 }\end{array}$ & $45 / 243,19 \%$ & $74 / 694,11 \%$ & $119 / 937,13 \%$ & 0.002 \\
(homozygotes) & $(2 \%)$ & $(0.3 \%)$ & $(1 \%)$ & \\
\hline $\begin{array}{l}\text { MBOAT7 } \\
\text { rs641738 }\end{array}$ & $158 / 244,65 \%$ & $443 / 691,64 \%$ & $601 / 935,64 \%$ & 0.044 \\
(homozygotes) & $(19 \%)$ & $(13 \%)$ & $(15 \%)$ & \\
\hline
\end{tabular}

Table 1. The prevalence of genetic polymorphisms. Successful genotyping for NAFLD+, n=243245; for NAFLD-, $n=691-703$; for total cohort, $n=935-948$. The statistical significance of difference between NAFLD- and NAFLD+ was calculated by Chi-Square. 


\begin{tabular}{|c|c|c|c|c|c|c|}
\hline & $\begin{array}{l}\text { NAFLD+, } \\
\text { MetS+ } \\
(\mathrm{n}=186)\end{array}$ & $\begin{array}{l}\text { NAFLD+, } \\
\text { MetS- } \\
(\mathrm{n}=63)\end{array}$ & $\mathrm{p}$-value & $\begin{array}{l}\text { NAFLD-, } \\
\text { MetS+ } \\
(\mathrm{n}=164)\end{array}$ & $\begin{array}{l}\text { NAFLD-, } \\
\text { MetS- } \\
(\mathrm{n}=545)\end{array}$ & $\begin{array}{l}\mathrm{p}- \\
\text { value }\end{array}$ \\
\hline age (years) & $52 \pm 6$ & $51 \pm 6$ & 0.175 & $51 \pm 6$ & $51 \pm 6$ & 0.693 \\
\hline $\begin{array}{l}\text { gender (female) } \\
\mathrm{n}(\%)\end{array}$ & $83(45 \%)$ & $22(35 \%)$ & 0.178 & $76(46 \%)$ & $327(60 \%)$ & 0.002 \\
\hline $\begin{array}{l}\text { PNPLA3 } \\
\text { rs738409 }\end{array}$ & $72(39 \%)$ & $32(52 \%)$ & 0.091 & $60(37 \%)$ & $209(39 \%)$ & 0.613 \\
\hline $\begin{array}{l}\text { TM6SF2 } \\
\text { rs58542926 }\end{array}$ & $30(16 \%)$ & $15(25 \%)$ & 0.158 & $15(9 \%)$ & $59(11 \%)$ & 0.472 \\
\hline $\begin{array}{l}\text { MBOAT7 } \\
\text { rs641738 }\end{array}$ & $\begin{array}{l}114 \\
(63 \%)\end{array}$ & $44(71 \%)$ & 0.236 & $\begin{array}{l}110 \\
(67 \%)\end{array}$ & $333(63 \%)$ & 0.304 \\
\hline $\begin{array}{l}\text { Smoking (pack } \\
\text { years) }\end{array}$ & $11 \pm 14$ & $12 \pm 14$ & 0.563 & $12 \pm 16$ & $7 \pm 11$ & $<0.001$ \\
\hline Diabetics, n (\%) & $62(33 \%)$ & $7(11 \%)$ & 0.001 & $17(10 \%)$ & $11(2 \%)$ & $<0.001$ \\
\hline HOMA-IR & $6.4 \pm 5.1$ & $2.7 \pm 1.7$ & $<0.001$ & $3.2 \pm 2.4$ & $1.8 \pm 1.3$ & $<0.001$ \\
\hline BMI $\left(\mathrm{kg} / \mathrm{m}^{2}\right)$ & $32.1 \pm 4.6$ & $28.2 \pm 4.8$ & $<0.001$ & $\begin{array}{l}29.9 \pm \\
3.8\end{array}$ & $25.4 \pm 3.3$ & $<0.001$ \\
\hline $\begin{array}{l}\text { Systolic blood } \\
\text { pressure } \\
(\mathrm{mmHg})\end{array}$ & $154 \pm 20$ & $151 \pm 20$ & 0.355 & $152 \pm 21$ & $144 \pm 22$ & $<0.001$ \\
\hline $\begin{array}{l}\text { Diastolic blood } \\
\text { pressure } \\
(\mathrm{mmHg})\end{array}$ & $93 \pm 10$ & $91 \pm 12$ & 0.328 & $91 \pm 11$ & $86 \pm 12$ & $<0.001$ \\
\hline LVMI $\left(\mathrm{g} / \mathrm{m}^{2}\right)$ & $139 \pm 39$ & $136 \pm 37$ & 0.629 & $137 \pm 37$ & $125 \pm 36$ & 0.001 \\
\hline
\end{tabular}




\begin{tabular}{|c|c|c|c|c|c|c|}
\hline GFR (ml/min) & $83 \pm 16$ & $87 \pm 15$ & 0.090 & $83 \pm 14$ & $84 \pm 16$ & 0.579 \\
\hline ALT (U/L) & $48 \pm 27$ & $39 \pm 21$ & 0.021 & $32 \pm 25$ & $24 \pm 10$ & $<0.001$ \\
\hline GGT (U/L) & $72 \pm 97$ & $46 \pm 41$ & 0.036 & $45 \pm 39$ & $30 \pm 26$ & $<0.001$ \\
\hline LDL (mmol/L) & $3.7 \pm 1.0$ & $3.4 \pm 1.0$ & 0.130 & $3.7 \pm 0.9$ & $3.4 \pm 0.9$ & 0.010 \\
\hline HDL (mmol/L) & $1.1 \pm 0.3$ & $1.4 \pm 0.4$ & $<0.001$ & $\begin{array}{l}1.1 \pm \\
\\
\\
0.3\end{array}$ & $1.5 \pm 0.4$ & $<0.001$ \\
\hline $\begin{array}{l}\text { Triglycerides } \\
(\mathrm{mmol} / \mathrm{L})\end{array}$ & $2.3 \pm 1.3$ & $1.4 \pm 0.5$ & $<0.001$ & $2.1 \pm 1.2$ & $1.1 \pm 0.5$ & $<0.001$ \\
\hline
\end{tabular}

Table 2. The baseline characteristics of study participants by the presence or absence of

NAFLD and MetS. For subjects with NAFLD, n=243-249, except for LVMI ( $n=245)$. For subjects without NAFLD, n=703-709, except for LVMI ( $\mathrm{n}=655)$, TM6SF2 rs58542926 ( $\mathrm{n}=694)$ and MBOAT7 rs641738 ( $\mathrm{n}=691)$. The categorical variables are presented as absolute count (with \%) and continuous variables as mean values \pm standard deviation. Abbreviations: ALT, Alanine Aminotransferase; BMI, Body Mass Index; GFR, Glomerulus Filtration Rate by the Chronic Kidney Disease Epidemiology Collaboration (CKD-EPI) equation; GGT, Gamma-

Glutamyltransferase; HDL, High-Density Lipoprotein; HOMA-IR, Homeostatic Model Assessment of Insulin Resistance; LDL, Low-Density Lipoprotein; LVMI, Left Ventricular Mass Index; MetS, Metabolic Syndrome. 


\begin{tabular}{|c|c|c|c|c|c|c|c|}
\hline $\begin{array}{l}\text { Gene } \\
\text { variant }\end{array}$ & $\begin{array}{l}\text { Non- } \\
\text { alcoholic } \\
\text { fatty liver } \\
\text { disease }\end{array}$ & $\begin{array}{l}\text { Number } \\
\text { of risk } \\
\text { allele } \\
\text { carriers } \\
\text { of all } \\
\text { subjects }\end{array}$ & $\begin{array}{l}\text { Death rate } \\
\text { in } \\
\text { subjects } \\
\text { with risk } \\
\text { allele }\end{array}$ & $\begin{array}{l}\text { Death rate } \\
\text { in } \\
\text { subjects } \\
\text { without } \\
\text { risk allele }\end{array}$ & $\begin{array}{l}\text { Hazard ratio } \\
\text { (risk allele } \\
\text { carrier vs. } \\
\text { non-carrier) }\end{array}$ & CI95\% & p-value \\
\hline \multirow[t]{3}{*}{$\begin{array}{l}\text { PNPLA3 } \\
\text { rs738409 }\end{array}$} & yes & $\begin{array}{l}104 / 245 \\
(42 \%)\end{array}$ & $\begin{array}{l}29 / 104 \\
(28 \%)\end{array}$ & $\begin{array}{l}40 / 141 \\
(28 \%)\end{array}$ & 1.049 & $0.650-1.692$ & 0.844 \\
\hline & no & $\begin{array}{l}269 / 703 \\
(38 \%)\end{array}$ & $\begin{array}{l}52 / 269 \\
(19 \%)\end{array}$ & $\begin{array}{l}81 / 434 \\
(19 \%)\end{array}$ & 1.032 & $0.729-1.462$ & 0.858 \\
\hline & combined & $\begin{array}{l}373 / 948 \\
(39 \%)\end{array}$ & $\begin{array}{l}81 / 373 \\
(22 \%)\end{array}$ & $\begin{array}{l}121 / 575 \\
(21 \%)\end{array}$ & 1.050 & $0.792-1.391$ & 0.736 \\
\hline \multirow[t]{3}{*}{$\begin{array}{l}\text { TM6SF2 } \\
\text { rs58542926 }\end{array}$} & yes & $\begin{array}{l}45 / 243 \\
(19 \%)\end{array}$ & $\begin{array}{l}10 / 45 \\
(22 \%)\end{array}$ & $\begin{array}{l}58 / 198 \\
(29 \%)\end{array}$ & 0.721 & $0.369-1.411$ & 0.340 \\
\hline & no & $\begin{array}{l}74 / 694 \\
(11 \%)\end{array}$ & $\begin{array}{l}10 / 74 \\
(14 \%)\end{array}$ & $\begin{array}{l}121 / 620 \\
(20 \%)\end{array}$ & 0.668 & $0.351-1.273$ & 0.220 \\
\hline & combined & $\begin{array}{l}119 / 937 \\
(13 \%)\end{array}$ & $\begin{array}{l}20 / 119 \\
(17 \%)\end{array}$ & $\begin{array}{l}179 / 818 \\
(22 \%)\end{array}$ & 0.741 & $0.467-1.177$ & 0.204 \\
\hline \multirow[t]{3}{*}{$\begin{array}{l}\text { MBOAT7 } \\
\text { rs641738 }\end{array}$} & yes & $\begin{array}{l}158 / 244 \\
(65 \%)\end{array}$ & $\begin{array}{l}43 / 158 \\
(27 \%)\end{array}$ & $\begin{array}{l}26 / 86 \\
(30 \%)\end{array}$ & 0.885 & $0.543-1.439$ & 0.621 \\
\hline & no & $\begin{array}{l}443 / 691 \\
(64 \%)\end{array}$ & $\begin{array}{l}76 / 443 \\
(17 \%)\end{array}$ & $\begin{array}{l}55 / 248 \\
(22 \%)\end{array}$ & 0.758 & $0.536-1.073$ & 0.118 \\
\hline & combined & $\begin{array}{l}601 / 935 \\
(64 \%)\end{array}$ & $\begin{array}{l}119 / 601 \\
(20 \%)\end{array}$ & $\begin{array}{l}81 / 334 \\
(24 \%)\end{array}$ & 0.800 & $0.603-1.061$ & 0.121 \\
\hline
\end{tabular}

Table 3. The Hazard Ratios for overall mortality by the carriers of PNPLA3 rs738409, TM6SF2 rs58542926 or MBOAT7 rs641738 compared to the non-carriers of these gene variants. The Cox Hazards model was used. 


\section{Figure Legends}

Fig. 1. Overall mortality by the presence of MetS and NAFLD. The Cox hazards model was used. MetS, Metabolic Syndrome; NAFLD, Non-Alcoholic Fatty Liver Disease.

Fig. 2. The Hazards Ratios for overall mortality by the number of gene polymorphisms (PNPLA3 rs738409, TM6SF2 rs58542926 and MBOAT7 rs641738). NAFLD, non-alcoholic fatty liver disease.

Fig. 3. CVD mortality by the presence or absence of PNPLA3 rs738409, TM6SF2 rs58542926, MBOAT7 rs641738 or MetS. The statistical significance of differences was measured using ChiSquare test. A. Subjects with NAFLD (n=243-245 for gene polymorphisms, n=249 for MetS), B. Subjects without NAFLD ( $\mathrm{n}=691-703$ for gene polymorphisms, $\mathrm{n}=709$ for MetS) and C. Total cohort ( $\mathrm{n}=935-948$ for gene polymorphisms, $\mathrm{n}=958$ for MetS). Abbreviation: CVD, cardiovascular disease. 


\section{References}

1. European Association for the Study of the Liver (EASL), European Association for the Study of Diabetes (EASD), European Association for the Study of Obesity (EASO). EASL-EASD-EASO Clinical Practice Guidelines for the management of non-alcoholic fatty liver disease. Diabetologia 2016;59:1121-40.

2. Younossi ZM, Koenig AB, Abdelatif D, Fazel Y, Henry L, Wymer M. Global epidemiology of nonalcoholic fatty liver disease-Meta-analytic assessment of prevalence, incidence, and outcomes. Hepatology 2016;64:73-84.

3. Rinella M, Charlton M. The globalization of nonalcoholic fatty liver disease: Prevalence and impact on world health. Hepatology 2016;64:19-22.

4. Byrne CD, Targher G. NAFLD: a multisystem disease. J Hepatol 2015;62:S47-64.

5. Karajamaki AJ, Hukkanen J, Ukkola O. The association of non-alcoholic fatty liver disease and atrial fibrillation: a review. Ann Med 2018;50:371-80.

6. Angulo P, Kleiner DE, Dam-Larsen S, Adams LA, Bjornsson ES, Charatcharoenwitthaya P, et al. Liver Fibrosis, but No Other Histologic Features, Is Associated With Long-term Outcomes of Patients With Nonalcoholic Fatty Liver Disease. Gastroenterology 2015;149:389-97.

7. Ekstedt M, Hagstrom H, Nasr P, Fredrikson M, Stal P, Kechagias S, et al. Fibrosis stage is the strongest predictor for disease-specific mortality in NAFLD after up to 33 years of follow-up. Hepatology 2015;61:1547-54.

8. Buzzetti E, Pinzani M, Tsochatzis EA. The multiple-hit pathogenesis of non-alcoholic fatty liver disease (NAFLD). Metabolism 2016;65:1038-48.

9. Mancina RM, Dongiovanni P, Petta S, Pingitore P, Meroni M, Rametta R, et al. The MBOAT7TMC4 Variant rs641738 Increases Risk of Nonalcoholic Fatty Liver Disease in Individuals of European Descent. Gastroenterology 2016;150:1219-30.

10. Dongiovanni P, Petta S, Maglio C, Fracanzani AL, Pipitone R, Mozzi E, et al. Transmembrane 6 superfamily member 2 gene variant disentangles nonalcoholic steatohepatitis from cardiovascular disease. Hepatology 2015;61:506-14.

11. Liu YL, Reeves HL, Burt AD, Tiniakos D, McPherson S, Leathart JB, et al. TM6SF2 rs58542926 influences hepatic fibrosis progression in patients with non-alcoholic fatty liver disease. Nat Commun 2014;5:4309.

12. Sookoian S, Pirola CJ. Meta-analysis of the influence of I148M variant of patatin-like phospholipase domain containing 3 gene (PNPLA3) on the susceptibility and histological severity of nonalcoholic fatty liver disease. Hepatology 2011;53:1883-94. 
13. Huang Y, Cohen JC, Hobbs HH. Expression and characterization of a PNPLA3 protein isoform (I148M) associated with nonalcoholic fatty liver disease. J Biol Chem 2011;286:37085-93.

14. Pingitore P, Pirazzi C, Mancina RM, Motta BM, Indiveri C, Pujia A, et al. Recombinant PNPLA3 protein shows triglyceride hydrolase activity and its I148M mutation results in loss of function. Biochim Biophys Acta 2014;1841:574-80.

15. Kotronen A, Johansson LE, Johansson LM, Roos C, Westerbacka J, Hamsten A, et al. A common variant in PNPLA3, which encodes adiponutrin, is associated with liver fat content in humans. Diabetologia 2009;52:1056-60.

16. Krawczyk M, Rau M, Schattenberg JM, Bantel H, Pathil A, Demir M, et al. Combined effects of the PNPLA3 rs738409, TM6SF2 rs58542926, and MBOAT7 rs641738 variants on NAFLD severity: a multicenter biopsy-based study. J Lipid Res 2017;58:247-55.

17. Dongiovanni P, Romeo S, Valenti L. Genetic Factors in the Pathogenesis of Nonalcoholic Fatty Liver and Steatohepatitis. Biomed Res Int 2015;2015:460190.

18. Dulai PS, Singh S, Patel J, Soni M, Prokop LJ, Younossi Z, et al. Increased risk of mortality by fibrosis stage in non-alcoholic fatty liver disease: Systematic Review and Meta-analysis.

Hepatology 2017;65:1557-65.

19. Meffert PJ, Repp KD, Volzke H, Weiss FU, Homuth G, Kuhn JP, et al. The PNPLA3 SNP rs738409:G allele is associated with increased liver disease-associated mortality but reduced overall mortality in a population-based cohort. J Hepatol 2018;68:858-60.

20. Kozlitina J, Smagris E, Stender S, Nordestgaard BG, Zhou HH, Tybjaerg-Hansen A, et al. Exome-wide association study identifies a TM6SF2 variant that confers susceptibility to nonalcoholic fatty liver disease. Nat Genet 2014;46:352-6.

21. Ruhanen H, Nidhina Haridas PA, Eskelinen EL, Eriksson O, Olkkonen VM, Kakela R. Depletion of TM6SF2 disturbs membrane lipid composition and dynamics in HuH7 hepatoma cells. Biochim Biophys Acta Mol Cell Biol Lipids 2017;1862:676-85.

22. Younossi ZM, Otgonsuren M, Venkatesan C, Mishra A. In patients with non-alcoholic fatty liver disease, metabolically abnormal individuals are at a higher risk for mortality while metabolically normal individuals are not. Metabolism 2013;62:352-60.

23. Karajamaki AJ, Bloigu R, Kauma H, Kesaniemi YA, Koivurova OP, Perkiomaki J, et al. Nonalcoholic fatty liver disease with and without metabolic syndrome: Different long-term outcomes. Metabolism 2017;66:55-63.

24. Rantala AO, Kauma H, Lilja M, Savolainen MJ, Reunanen A, Kesaniemi YA. Prevalence of the metabolic syndrome in drug-treated hypertensive patients and control subjects. J Intern Med 1999;245:163-74.

25. Ballestri S, Romagnoli D, Nascimbeni F, Francica G, Lonardo A. Role of ultrasound in the diagnosis and treatment of nonalcoholic fatty liver disease and its complications. Expert Rev Gastroenterol Hepatol 2015;9:603-27. 
26. Hanley AJ, Karter AJ, Williams K, Festa A, D'Agostino RB,Jr, Wagenknecht LE, et al. Prediction of type 2 diabetes mellitus with alternative definitions of the metabolic syndrome: the Insulin Resistance Atherosclerosis Study. Circulation 2005;112:3713-21.

27. Matthews DR, Hosker JP, Rudenski AS, Naylor BA, Treacher DF, Turner RC. Homeostasis model assessment: insulin resistance and beta-cell function from fasting plasma glucose and insulin concentrations in man. Diabetologia 1985;28:412-9.

28. Petaja EM, Yki-Jarvinen H. Definitions of Normal Liver Fat and the Association of Insulin Sensitivity with Acquired and Genetic NAFLD-A Systematic Review. Int J Mol Sci 2016;17.

29. Franko A, Merkel D, Kovarova M, Hoene M, Jaghutriz BA, Heni M, et al. Dissociation of Fatty Liver and Insulin Resistance in I148M PNPLA3 Carriers: Differences in Diacylglycerol (DAG) FA18:1 Lipid Species as a Possible Explanation. Nutrients 2018;10.

30. Luukkonen PK, Zhou Y, Sadevirta S, Leivonen M, Arola J, Oresic M, et al. Hepatic ceramides dissociate steatosis and insulin resistance in patients with non-alcoholic fatty liver disease. $\mathrm{J}$ Hepatol 2016;64:1167-75.

31. Luukkonen PK, Zhou Y, Nidhina Haridas PA, Dwivedi OP, Hyotylainen T, Ali A, et al. Impaired hepatic lipid synthesis from polyunsaturated fatty acids in TM6SF2 E167K variant carriers with NAFLD. J Hepatol 2017;67:128-36.

32. Musso G, Gambino R, Cassader M. Cholesterol metabolism and the pathogenesis of nonalcoholic steatohepatitis. Prog Lipid Res 2013;52:175-91.

33. Mota M, Banini BA, Cazanave SC, Sanyal AJ. Molecular mechanisms of lipotoxicity and glucotoxicity in nonalcoholic fatty liver disease. Metabolism 2016;65:1049-61.

34. Mahady SE, George J. Exercise and diet in the management of nonalcoholic fatty liver disease. Metabolism 2016;65:1172-82.

35. Luukkonen PK, Zhou Y, Hyotylainen T, Leivonen M, Arola J, Orho-Melander M, et al. The MBOAT7 variant rs641738 alters hepatic phosphatidylinositols and increases severity of nonalcoholic fatty liver disease in humans. J Hepatol 2016;65:1263-5.

36. D'Souza K, Epand RM. Enrichment of phosphatidylinositols with specific acyl chains. Biochim Biophys Acta 2014;1838:1501-8.

37. Umano GR, Caprio S, Di Sessa A, Chalasani N, Dykas DJ, Pierpont B, et al. The rs626283 Variant in the MBOAT7 Gene is Associated with Insulin Resistance and Fatty Liver in Caucasian Obese Youth. Am J Gastroenterol 2018;113:376-83.

38. Asrih M, Jornayvaz FR. Metabolic syndrome and nonalcoholic fatty liver disease: Is insulin resistance the link? Mol Cell Endocrinol 2015;418 Pt 1:55-65.

39. Yki-Jarvinen H. Non-alcoholic fatty liver disease as a cause and a consequence of metabolic syndrome. Lancet Diabetes Endocrinol 2014;2:901-10. 
40. Smith U. Abdominal obesity: a marker of ectopic fat accumulation. J Clin Invest 2015;125:1790-2.

41. Matloch Z, Kotulak T, Haluzik M. The role of epicardial adipose tissue in heart disease. Physiol Res 2016;65:23-32.

42. Graner M, Nyman K, Siren R, Pentikainen MO, Lundbom J, Hakkarainen A, et al. Ectopic fat depots and left ventricular function in nondiabetic men with nonalcoholic fatty liver disease. Circ Cardiovasc Imaging 2014;8:(1).

43. Haslam DB. Nonalcoholic steatohepatitis and the intestinal microbiota. Hepatology 2017;65:401-3.

44. Machado MV, Cortez-Pinto H. Diet, Microbiota, Obesity, and NAFLD: A Dangerous Quartet. Int J Mol Sci 2016;17:481.

45. Pussinen PJ, Havulinna AS, Lehto M, Sundvall J, Salomaa V. Endotoxemia is associated with an increased risk of incident diabetes. Diabetes Care 2011;34:392-7.

46. Lassenius MI, Pietilainen KH, Kaartinen K, Pussinen PJ, Syrjanen J, Forsblom C, et al. Bacterial endotoxin activity in human serum is associated with dyslipidemia, insulin resistance, obesity, and chronic inflammation. Diabetes Care 2011;34:1809-15.

47. Simons N, Isaacs A, Koek GH, Kuc S, Schaper NC, Brouwers MCGJ. PNPLA3, TM6SF2, and MBOAT7 Genotypes and Coronary Artery Disease. Gastroenterology 2017;152:912-3.

48. Pirola CJ, Sookoian S. The dual and opposite role of the TM6SF2-rs58542926 variant in protecting against cardiovascular disease and conferring risk for nonalcoholic fatty liver: A metaanalysis. Hepatology 2015;62:1742-56.

49. Petta S, Valenti L, Marchesini G, Di Marco V, Licata A, Camma C, et al. PNPLA3 GG genotype and carotid atherosclerosis in patients with non-alcoholic fatty liver disease. PLoS One 2013;8(9):e74089.

50. Di Costanzo A, D'Erasmo L, Polimeni L, Baratta F, Coletta P, Di Martino M, et al. Nonalcoholic fatty liver disease and subclinical atherosclerosis: A comparison of metabolically- versus genetically-driven excess fat hepatic storage. Atherosclerosis 2017;257:232-9.

51. Posadas-Sanchez R, Lopez-Uribe AR, Posadas-Romero C, Perez-Hernandez N, RodriguezPerez JM, Ocampo-Arcos WA, et al. Association of the I148M/PNPLA3 (rs738409) polymorphism with premature coronary artery disease, fatty liver, and insulin resistance in type 2 diabetic patients and healthy controls. The GEA study. Immunobiology 2017;222:960-6.

52. Lauridsen BK, Stender S, Kristensen TS, Kofoed KF, Kober L, Nordestgaard BG, et al. Liver fat content, non-alcoholic fatty liver disease, and ischaemic heart disease: Mendelian randomization and meta-analysis of 279013 individuals. Eur Heart J 2018;39:385-93.

53. Mantovani A. Not all NAFLD patients are the same: We need to find a personalized therapeutic approach. Dig Liver Dis 2019;51:176-7. 
54. Alexander M, Loomis AK, van der Lei J, Duarte-Salles T, Prieto-Alhambra D, Ansell D, et al. Non-alcoholic fatty liver disease and risk of incident acute myocardial infarction and stroke: findings from matched cohort study of 18 million European adults. BMJ 2019;367:15367.

55. Musso G, Cassader M, Paschetta E, Gambino R. TM6SF2 may drive postprandial lipoprotein cholesterol toxicity away from the vessel walls to the liver in NAFLD. J Hepatol 2016;64:979-981.

56. Kastarinen MJ, Salomaa VV, Vartiainen EA, Jousilahti PJ, Tuomilehto JO, Puska PM, et al. Trends in blood pressure levels and control of hypertension in Finland from 1982 to 1997. J Hypertens 1998;16:1379-87.

57. Webb M, Yeshua H, Zelber-Sagi S, Santo E, Brazowski E, Halpern Z, et al. Diagnostic value of a computerized hepatorenal index for sonographic quantification of liver steatosis. AJR Am J Roentgenol 2009;192:909-14. 


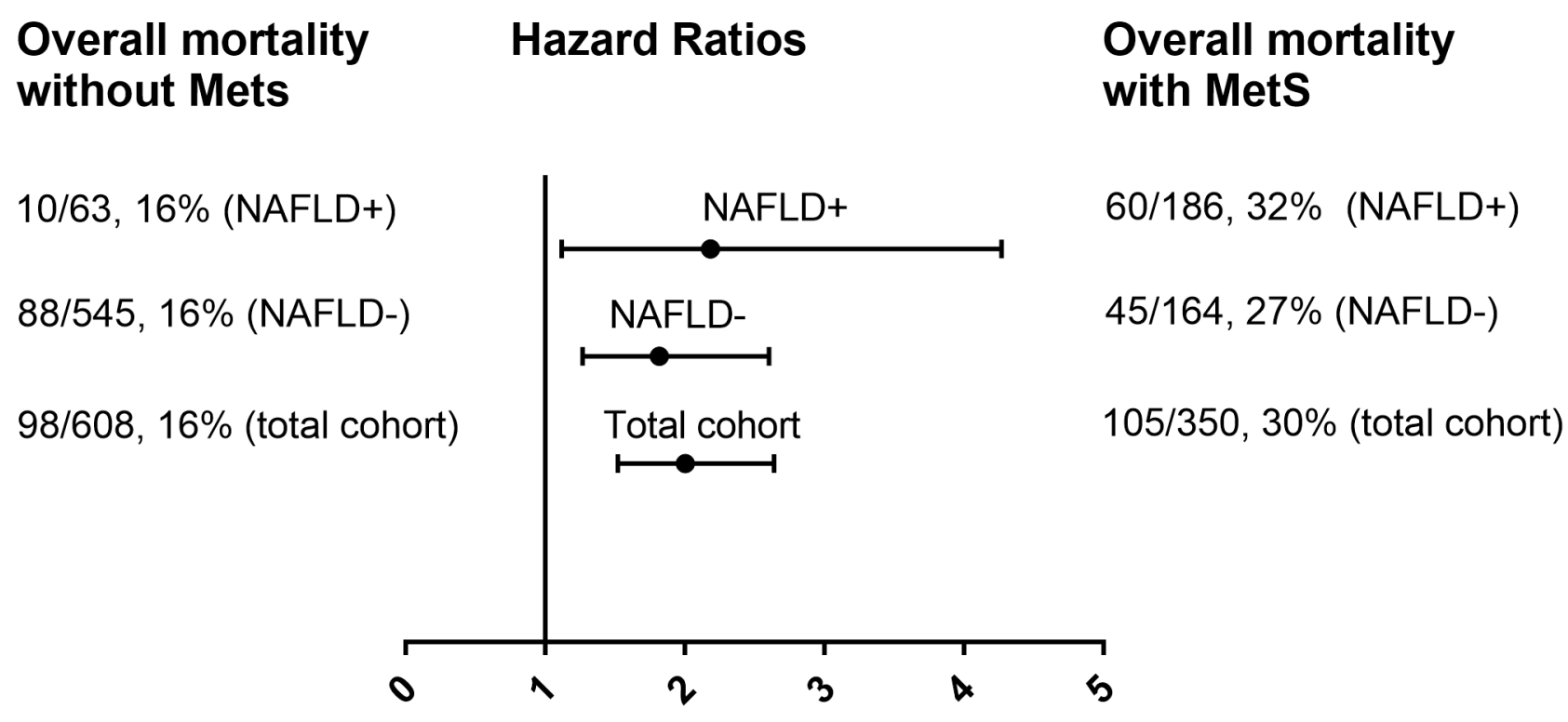

Hazard Ratio with $95 \%$ confidence interval

The Hazard Ratios with $95 \% \mathrm{Cl}$ with MetS vs. without MetS were: $2.186(1.118-4.271, p=0.022)$ and after adjustments, $2.054(1.011-4.173, p=0.046)$ for subjects with NAFLD; $1.818(1.269-2.604, p=0.001)$ and after adjustments, $1.616(1.056-2.473, p=0.027)$ subjects without NAFLD; 2.005 (1.522-2.640, $p<0.001)$ and after adjustments, $1.718(1.231-2.399, p=0.001)$ for total cohort. The multiple adjustments were made for age, sex, BMI, smoking and the original study group. 


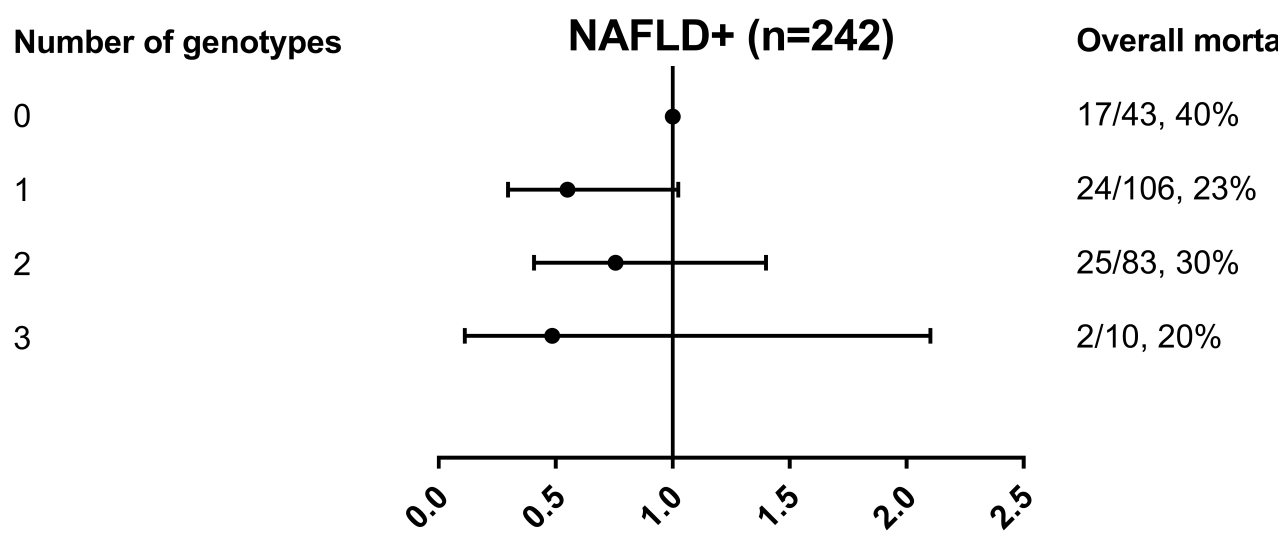

Hazard Ratio with $95 \%$ confidence interval

The Hazard Ratios with $95 \% \mathrm{Cl}$ were $0.551(0.296-1.025 ; \mathrm{p}=0.060)$ for 1 risk genotype, 0.756 $(0.408-1.400 ; p=0.374)$ for 2 risk genotypes and $0.485(0.112-2.102 ; p=0.344)$ for 3 risk genotypes.

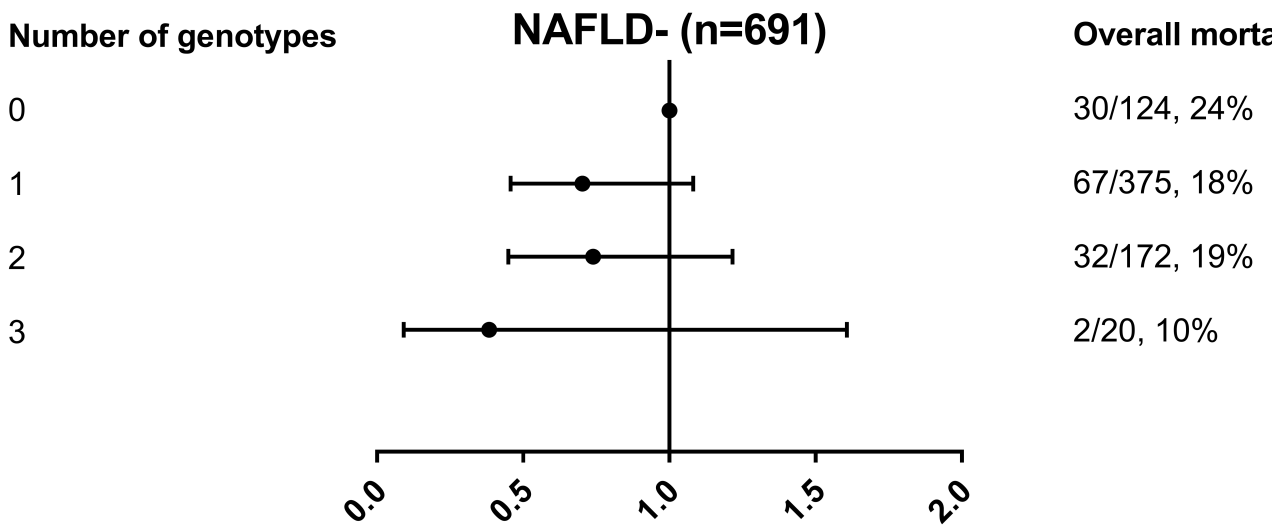

Hazard Ratio with $95 \%$ confidence interval

The Hazard Ratios with $95 \% \mathrm{Cl}$ were 0.703 (0.457-1.082; $p=0.109)$ for 1 risk genotype, 0.739 $(0.449-1.216 ; p=0.234)$ for 2 risk genotypes and $0.384(0.092-1.607$ : $p=0.190)$ for 3 risk genotypes.

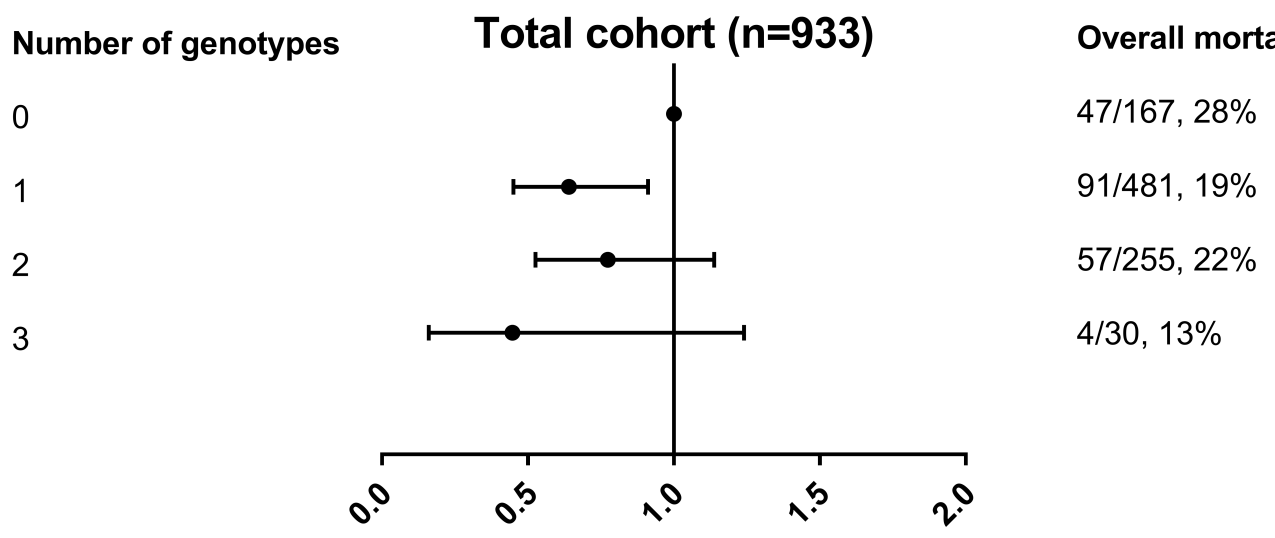

Hazard Ratio with $95 \%$ confidence interval

The Hazard Ratios with $95 \% \mathrm{Cl}$ were 0.641 (0.451-0.912; $p=0.013$. After adjustments for age, sex, BMI, smoking and original study group, $0.686(0.480-0.981 ; p=0.039)$ for 1 risk genotype, 0.774 $(0.526-1.138 ; p=0.195)$ for 2 risk genotypes and $0.447(0.161-1.240 ; p=0.083)$ for 3 risk genotypes. 

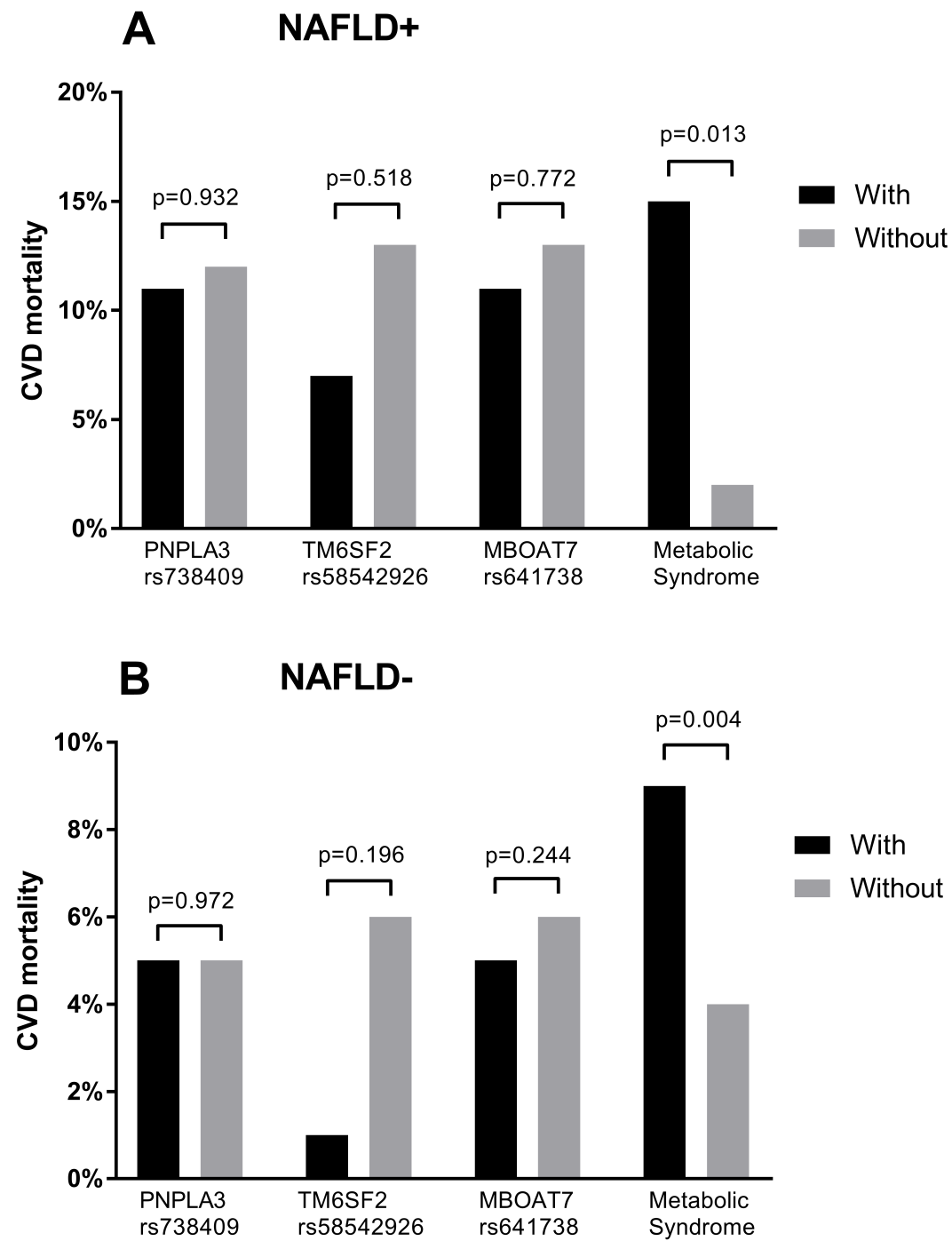

C Total cohort

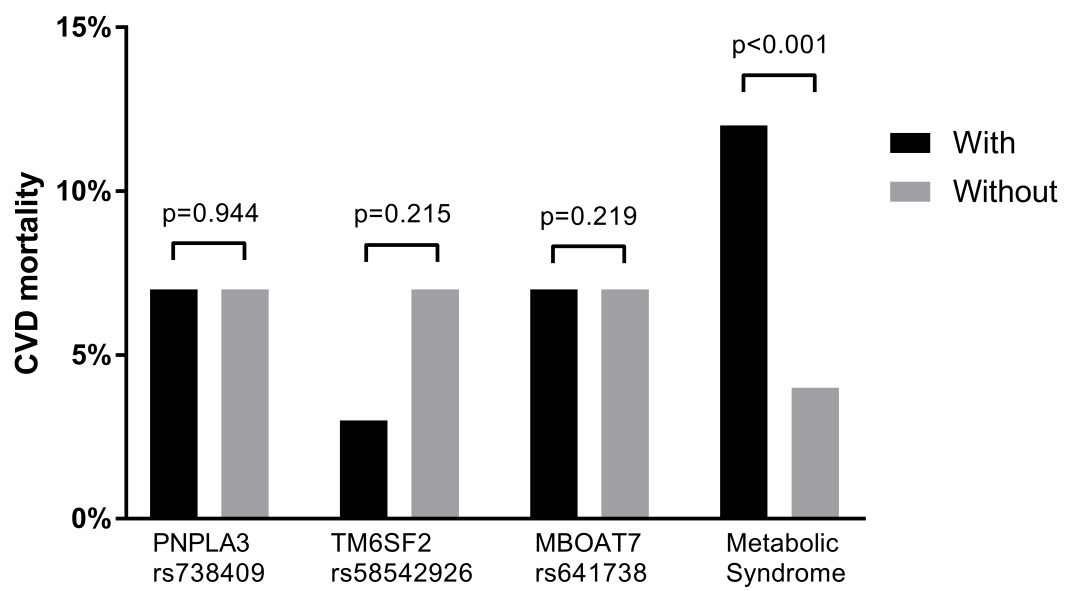




\begin{tabular}{|c|c|c|c|}
\hline & $\begin{array}{l}\text { Subjects with MetS } \\
(n=350)\end{array}$ & $\begin{array}{l}\text { Subjects without MetS } \\
(\mathrm{n}=608)\end{array}$ & p-value \\
\hline BMI $\left(\mathrm{kg} / \mathrm{m}^{2}\right)$ & $31.1 \pm 4.4$ & $25.7 \pm 3.5$ & $<0.001$ \\
\hline Smoking (pack years) & $11 \pm 15$ & $7 \pm 12$ & $<0.001$ \\
\hline HOMA (Ummol/L ${ }^{2}$ ) & $4.9 \pm 4.4$ & $1.9 \pm 1.4$ & $<0.001$ \\
\hline $\begin{array}{l}\text { Systolic blood } \\
\text { pressure (mmHg) }\end{array}$ & $153 \pm 20$ & $144 \pm 22$ & $<0.001$ \\
\hline $\begin{array}{l}\text { Diastolic blood } \\
\text { pressure (mmHg) }\end{array}$ & $92 \pm 10$ & $87 \pm 13$ & $<0.001$ \\
\hline ALT (U/L) & $41 \pm 27$ & $25 \pm 13$ & $<0.001$ \\
\hline GGT (U/L) & $60 \pm 76$ & $32 \pm 28$ & $<0.001$ \\
\hline $\operatorname{LVMI}\left(\mathrm{g} / \mathrm{m}^{2}\right)$ & $138 \pm 38$ & $126 \pm 37$ & $<0.001$ \\
\hline $\begin{array}{l}\text { LDL cholesterol } \\
(\mathrm{mmol} / \mathrm{L})\end{array}$ & $3.7 \pm 0.9$ & $3.4 \pm 0.9$ & 0.001 \\
\hline $\begin{array}{l}\text { HDL cholesterol } \\
(\mathrm{mmol} / \mathrm{L})\end{array}$ & $1.1 \pm 0.3$ & $1.5 \pm 0.4$ & $<0.001$ \\
\hline $\begin{array}{l}\text { Triglycerides } \\
(\mathrm{mmol} / \mathrm{L})\end{array}$ & $2.2 \pm 1.3$ & $1.2 \pm 0.5$ & $<0.001$ \\
\hline
\end{tabular}

\section{Supplementary Table 1. The variables with statistically significant differences in the total}

cohort by the presence or absence of metabolic syndrome. The categorical variables are presented as absolute numbers (with \%) and continuous variables as mean values \pm standard deviation. Abbreviations: ALT, Alanine Aminotransferase; BMI, Body Mass Index; GGT, GammaGlutamyltransferase; HDL, High-Density Lipoprotein; HOMA, Homeostatic Model Assessment of 
Insulin Resistance; LDL, Low-Density Lipoprotein; LVMI, Left Ventricular Mass Index; MetS, Metabolic Syndrome. 


\begin{tabular}{|c|c|c|c|c|c|c|c|c|c|}
\hline & $\begin{array}{l}\text { PNPLA3 } \\
\text { risk } \\
\text { allele } \\
\text { carrier } \\
(\mathrm{n}=104)\end{array}$ & $\begin{array}{l}\text { PNPLA3 } \\
\text { no risk } \\
\text { allele } \\
\text { carrier } \\
(\mathrm{n}=141)\end{array}$ & $\begin{array}{l}\mathrm{p}- \\
\text { value }\end{array}$ & $\begin{array}{l}\text { TM6SF2 } \\
\text { risk } \\
\text { allele } \\
\text { carrier } \\
(n=45)\end{array}$ & $\begin{array}{l}\text { TM6SF2 } \\
\text { no risk } \\
\text { allele } \\
\text { carrier } \\
(\mathrm{n}=198)\end{array}$ & $\begin{array}{l}\mathrm{p}- \\
\text { value }\end{array}$ & $\begin{array}{l}\text { MBOAT7 } \\
\text { risk allele } \\
\text { carrier } \\
(\mathrm{n}=158)\end{array}$ & $\begin{array}{l}\text { MBOAT7 } \\
\text { no risk } \\
\text { allele } \\
\text { carrier } \\
(\mathrm{n}=86)\end{array}$ & $\begin{array}{l}\mathrm{p}- \\
\text { value }\end{array}$ \\
\hline age (years) & $53 \pm 6$ & $51 \pm 6$ & 0.088 & $51 \pm 6$ & $52 \pm 6$ & 0.075 & $52 \pm 6$ & $53 \pm 5$ & 0.212 \\
\hline $\begin{array}{l}\text { gender } \\
\text { (female) n } \\
(\%)\end{array}$ & $45(43 \%)$ & $60(43 \%)$ & 0.911 & $22(49 \%)$ & $82(41 \%)$ & 0.360 & $67(42 \%)$ & $38(44 \%)$ & 0.788 \\
\hline $\begin{array}{l}\text { Smoking } \\
\text { (pack years) }\end{array}$ & $11 \pm 15$ & $12 \pm 14$ & 0.677 & $10 \pm 12$ & $12 \pm 15$ & 0.365 & $10 \pm 13$ & $13 \pm 16$ & 0.173 \\
\hline MetS & $72(69 \%)$ & $\begin{array}{l}111 \\
(79 \%)\end{array}$ & 0.091 & $30(67 \%)$ & $\begin{array}{l}152 \\
(77 \%)\end{array}$ & 0.158 & $114(72 \%)$ & $68(79 \%)$ & 0.236 \\
\hline $\begin{array}{l}\text { Diabetics, } \mathrm{n} \\
(\%)\end{array}$ & $27(26 \%)$ & $41(29 \%)$ & 0.590 & $12(27 \%)$ & $55(28 \%)$ & 0.880 & $39(25 \%)$ & $28(33 \%)$ & 0.188 \\
\hline $\begin{array}{l}\text { HOMA } \\
\left(\mathrm{Ummol} /\left(\mathrm{L}^{2}\right)\right.\end{array}$ & $5.3 \pm 5.6$ & $5.6 \pm 4.1$ & 0.725 & $6.2 \pm 5.5$ & $5.3 \pm 4.6$ & 0.297 & $5.3 \pm 4.5$ & $5.8 \pm 5.4$ & 0.360 \\
\hline BMI $\left(\mathrm{kg} / \mathrm{m}^{2}\right)$ & $\begin{array}{l}30.4 \pm \\
4.7\end{array}$ & $\begin{array}{l}31.8 \pm \\
5.0\end{array}$ & 0.027 & $\begin{array}{l}31.6 \pm \\
5.6\end{array}$ & $\begin{array}{l}31.2 \pm \\
4.8\end{array}$ & 0.670 & $31.3 \pm 5.1$ & $31.0 \pm 4.7$ & 0.655 \\
\hline $\begin{array}{l}\text { Systolic } \\
\text { blood } \\
\text { pressure } \\
(\mathrm{mmHg})\end{array}$ & $153 \pm 21$ & $153 \pm 20$ & 0.943 & $154 \pm 23$ & $153 \pm 20$ & 0.668 & $153 \pm 20$ & $153 \pm 21$ & 0.978 \\
\hline Diastolic & $92 \pm 11$ & $92 \pm 10$ & 0.802 & $93 \pm 12$ & $92 \pm 10$ & 0.570 & $93 \pm 11$ & $91 \pm 10$ & 0.412 \\
\hline
\end{tabular}




\begin{tabular}{|c|c|c|c|c|c|c|c|c|c|}
\hline $\begin{array}{l}\text { blood } \\
\text { pressure } \\
(\mathrm{mmHg})\end{array}$ & & & & & & & & & \\
\hline LVMI $\left(\mathrm{g} / \mathrm{m}^{2}\right)$ & $134 \pm 40$ & $141 \pm 38$ & 0.210 & $128 \pm 36$ & $141 \pm 39$ & 0.076 & $138 \pm 37$ & $138 \pm 43$ & 0.970 \\
\hline $\begin{array}{l}\text { GFR } \\
(\mathrm{ml} / \mathrm{min})\end{array}$ & $84 \pm 15$ & $84 \pm 16$ & 0.836 & $86 \pm 16$ & $84 \pm 15$ & 0.322 & $84 \pm 16$ & $84 \pm 16$ & 0.982 \\
\hline ALT (U/L) & $48 \pm 30$ & $44 \pm 23$ & 0.198 & $44 \pm 19$ & $46 \pm 27$ & 0.641 & $47 \pm 29$ & $42 \pm 19$ & 0.115 \\
\hline GGT (U/L) & $73 \pm 102$ & $60 \pm 75$ & 0.262 & $44 \pm 27$ & $67 \pm 84$ & 0.071 & $75 \pm 106$ & $48 \pm 25$ & 0.019 \\
\hline $\begin{array}{l}\mathrm{LDL} \\
(\mathrm{mmol} / \mathrm{L})\end{array}$ & $3.5 \pm 1.0$ & $3.7 \pm 1.0$ & 0.242 & $3.4 \pm 1.1$ & $3.7 \pm 0.9$ & 0.052 & $3.5 \pm 1.0$ & $3.7 \pm 1.0$ & 0.217 \\
\hline $\begin{array}{l}\text { HDL } \\
(\mathrm{mmol} / \mathrm{L})\end{array}$ & $1.2 \pm 0.3$ & $1.2 \pm 0.4$ & 0.936 & $1.2 \pm 0.3$ & $1.2 \pm 0.3$ & 0.897 & $1.2 \pm 0.3$ & $1.2 \pm 0.4$ & 0.978 \\
\hline $\begin{array}{l}\text { Triglycerides } \\
(\mathrm{mmol} / \mathrm{L})\end{array}$ & $2.1 \pm 1.3$ & $2.1 \pm 1.2$ & 0.757 & $2.1 \pm 1.4$ & $2.1 \pm 1.2$ & 0.829 & $2.1 \pm 1.2$ & $2.1 \pm 1.4$ & 0.920 \\
\hline
\end{tabular}

Supplementary Table 2. The baseline characteristics of study participants with NAFLD by the presence or absence of each gene polymorphism. For PNPLA3 rs738409, n=242-245 (for LVMI, n=210); TM6SF2 rs58542926, n=240-243 (for LVMI, n=210); MBOAT7 rs641738, n=241-244 (for LVMI, n=209). The categorical variables are presented as absolute numbers (with \%) and continuous variables as mean values \pm standard deviation. Abbreviations: ALT, Alanine Aminotransferase; BMI, Body Mass Index; GFR, Glomerulus Filtration Rate by the Chronic Kidney Disease Epidemiology Collaboration (CKD-EPI) equation; GGT, GammaGlutamyltransferase; HDL, High-Density Lipoprotein; HOMA, Homeostatic Model Assessment of Insulin Resistance; LVMI, Left Ventricular Mass Index; MetS, Metabolic Syndrome. 


\begin{tabular}{|c|c|c|c|c|c|c|c|c|c|}
\hline & $\begin{array}{l}\text { PNPLA3 } \\
\text { risk } \\
\text { allele } \\
\text { carrier } \\
(\mathrm{n}=269)\end{array}$ & $\begin{array}{l}\text { PNPLA3 } \\
\text { no risk } \\
\text { allele } \\
\text { carrier } \\
(\mathrm{n}=434)\end{array}$ & $\begin{array}{l}\mathrm{p}- \\
\text { value }\end{array}$ & $\begin{array}{l}\text { TM6SF2 } \\
\text { risk } \\
\text { allele } \\
\text { carrier } \\
(\mathrm{n}=74)\end{array}$ & $\begin{array}{l}\text { TM6SF2 } \\
\text { no risk } \\
\text { allele } \\
\text { carrier } \\
(\mathrm{n}=620)\end{array}$ & $\begin{array}{l}\mathrm{p}- \\
\text { value }\end{array}$ & $\begin{array}{l}\text { MBOAT7 } \\
\text { risk allele } \\
\text { carrier } \\
(\mathrm{n}=443)\end{array}$ & $\begin{array}{l}\text { MBOAT7 } \\
\text { no risk } \\
\text { allele } \\
\text { carrier } \\
(\mathrm{n}=248)\end{array}$ & $\begin{array}{l}\mathrm{p}- \\
\text { value }\end{array}$ \\
\hline age (years) & $51 \pm 6$ & $51 \pm 6$ & 0.271 & $51 \pm 5$ & $51 \pm 6$ & 0.751 & $51 \pm 6$ & $52 \pm 6$ & 0.143 \\
\hline $\begin{array}{l}\text { gender } \\
(\text { female) } \mathrm{n} \\
(\%)\end{array}$ & $\begin{array}{l}156 \\
(58 \%)\end{array}$ & $\begin{array}{l}246 \\
(57 \%)\end{array}$ & 0.397 & $41(55 \%)$ & $\begin{array}{l}358 \\
(58 \%)\end{array}$ & 0.701 & $259(58 \%)$ & $140(56 \%)$ & 0.607 \\
\hline $\begin{array}{l}\text { Smoking } \\
\text { (pack years) }\end{array}$ & $8 \pm 12$ & $8 \pm 13$ & 0.650 & $7 \pm 13$ & $8 \pm 13$ & 0.431 & $8 \pm 13$ & $8 \pm 13$ & 0.904 \\
\hline MetS & $60(22 \%)$ & $\begin{array}{l}104 \\
(24 \%)\end{array}$ & 0.613 & $15(20 \%)$ & $\begin{array}{l}149 \\
(24 \%)\end{array}$ & 0.472 & $110(25 \%)$ & $53(21 \%)$ & 0.304 \\
\hline $\begin{array}{l}\text { Diabetics, } \mathrm{n} \\
(\%)\end{array}$ & $9(3 \%)$ & $19(4 \%)$ & 0.319 & $2(3 \%)$ & $26(4 \%)$ & 0.538 & $15(3 \%)$ & $12(5 \%)$ & 0.344 \\
\hline $\begin{array}{l}\text { HOMA } \\
\left(\mathrm{Ummol} /\left(\mathrm{L}^{2}\right)\right.\end{array}$ & $2.1 \pm 2.0$ & $2.2 \pm 1.6$ & 0.418 & $1.9 \pm 1.1$ & $2.2 \pm 1.8$ & 0.314 & $2.1 \pm 1.7$ & $2.2 \pm 1.9$ & 0.509 \\
\hline BMI $\left(\mathrm{kg} / \mathrm{m}^{2}\right)$ & $\begin{array}{l}26.3 \pm \\
3.9\end{array}$ & $\begin{array}{l}26.6 \pm \\
3.9\end{array}$ & 0.342 & $\begin{array}{l}26.8 \pm \\
4.0\end{array}$ & $\begin{array}{l}26.4 \pm \\
3.9\end{array}$ & 0.491 & $26.6 \pm 3.9$ & $26.2 \pm 3.8$ & 0.217 \\
\hline $\begin{array}{l}\text { Systolic } \\
\text { blood } \\
\text { pressure } \\
(\mathrm{mmHg})\end{array}$ & $143 \pm 21$ & $147 \pm 22$ & 0.033 & $145 \pm 21$ & $146 \pm 22$ & 0.650 & $145 \pm 22$ & $147 \pm 23$ & 0.164 \\
\hline Diastolic & $88 \pm 12$ & $87 \pm 13$ & 0.345 & $87 \pm 14$ & $87 \pm 12$ & 0.760 & $87 \pm 12$ & $88 \pm 13$ & 0.399 \\
\hline
\end{tabular}




\begin{tabular}{|c|c|c|c|c|c|c|c|c|c|}
\hline $\begin{array}{l}\text { blood } \\
\text { pressure } \\
(\mathrm{mmHg})\end{array}$ & & & & & & & & & \\
\hline LVMI $\left(\mathrm{g} / \mathrm{m}^{2}\right)$ & $126 \pm 38$ & $128 \pm 36$ & 0.490 & $130 \pm 33$ & $127 \pm 37$ & 0.499 & $126 \pm 36$ & $129 \pm 38$ & 0.431 \\
\hline $\begin{array}{l}\text { GFR-Epi } \\
(\mathrm{ml} / \mathrm{min})\end{array}$ & $85 \pm 15$ & $83 \pm 15$ & 0.265 & $85 \pm 16$ & $84 \pm 15$ & 0.467 & $84 \pm 15$ & $84 \pm 15$ & 0.990 \\
\hline ALT (U/L) & $26 \pm 12$ & $26 \pm 17$ & 0.619 & $24 \pm 9$ & $26 \pm 16$ & 0.354 & $27 \pm 17$ & $24 \pm 11$ & 0.058 \\
\hline GGT (U/L) & $34 \pm 35$ & $33 \pm 26$ & 0.586 & $34 \pm 30$ & $34 \pm 30$ & 0.913 & $34 \pm 29$ & $33 \pm 31$ & 0.532 \\
\hline $\begin{array}{l}\mathrm{LDL} \\
(\mathrm{mmol} / \mathrm{L})\end{array}$ & $3.5 \pm 1.0$ & $3.5 \pm 0.9$ & 0.592 & $3.3 \pm 0.8$ & $3.5 \pm 0.9$ & 0.068 & $3.5 \pm 0.9$ & $3.5 \pm 1.0$ & 0.738 \\
\hline $\begin{array}{l}\text { HDL } \\
(\mathrm{mmol} / \mathrm{L})\end{array}$ & $\begin{array}{l}1.44 \pm \\
0.38\end{array}$ & $\begin{array}{l}1.38 \pm \\
0.37\end{array}$ & 0.033 & $1.4 \pm 0.4$ & $1.4 \pm 0.4$ & 0.448 & $1.4 \pm 0.4$ & $1.4 \pm 0.4$ & 0.703 \\
\hline $\begin{array}{l}\text { Triglycerides } \\
(\mathrm{mmol} / \mathrm{L})\end{array}$ & $1.3 \pm 0.7$ & $1.4 \pm 0.9$ & 0.397 & $1.4 \pm 1.4$ & $1.4 \pm 0.7$ & 0.441 & $1.4 \pm 0.9$ & $1.3 \pm 0.6$ & 0.096 \\
\hline
\end{tabular}

Supplementary Table 3. The baseline characteristics of study participants without NAFLD by the presence or absence of each gene polymorphism. For PNPLA3 rs738409, n=701-703 (for LVMI, n=648); TM6SF2 rs58542926, n=692-694 (for LVMI, n=640); MBOAT7 rs641738, n=689_691 (for LVMI, n=637). The categorical variables are presented as absolute numbers (with \%) and continuous variables as mean values \pm standard deviation. Abbreviations: ALT, Alanine Aminotransferase; BMI, Body Mass Index; GFR, Glomerulus Filtration Rate by the Chronic Kidney Disease Epidemiology Collaboration (CKD-EPI) equation; GGT, Gamma-

Glutamyltransferase; HDL, High-Density Lipoprotein; HOMA, Homeostatic Model Assessment of Insulin Resistance; LDL, Low-Density Lipoprotein; LVMI, Left Ventricular Mass Index; MetS, Metabolic Syndrome. 



\begin{tabular}{|c|c|c|c|c|}
\hline & $\begin{array}{l}\text { Non- } \\
\text { alcoholic } \\
\text { fatty liver } \\
\text { disease }\end{array}$ & $\begin{array}{l}\text { CVD death } \\
\text { rate in } \\
\text { subjects } \\
\text { with risk } \\
\text { allele or } \\
\text { MetS }\end{array}$ & $\begin{array}{l}\text { CVD death } \\
\text { rate in subjects } \\
\text { without risk } \\
\text { allele or MetS }\end{array}$ & p-value \\
\hline \multirow[t]{3}{*}{$\begin{array}{l}\text { PNPLA3 } \\
\text { rs738409 }\end{array}$} & yes $(n=245)$ & $\begin{array}{l}11 / 104 \\
(11 \%)\end{array}$ & $17 / 141(12 \%)$ & 0.932 \\
\hline & no $(n=703)$ & $\begin{array}{l}14 / 269 \\
(5 \%)\end{array}$ & $23 / 434(5 \%)$ & 0.972 \\
\hline & $\begin{array}{l}\text { combined } \\
(\mathrm{n}=948)\end{array}$ & $\begin{array}{l}25 / 373 \\
(7 \%)\end{array}$ & 40/575 (7\%) & 0.944 \\
\hline \multirow[t]{3}{*}{$\begin{array}{l}\text { TM6SF2 } \\
\text { rs58542926 }\end{array}$} & yes $(n=243)$ & $3 / 45(7 \%)$ & $25 / 198(13 \%)$ & 0.518 \\
\hline & no $(n=694)$ & $1 / 74(1 \%)$ & $36 / 620(6 \%)$ & 0.196 \\
\hline & $\begin{array}{l}\text { combined } \\
(n=937)\end{array}$ & $4 / 119(3 \%)$ & $61 / 818(7 \%)$ & 0.215 \\
\hline \multirow[t]{3}{*}{$\begin{array}{l}\text { MBOAT7 } \\
\text { rs641738 }\end{array}$} & yes $(n=244)$ & $\begin{array}{l}17 / 158 \\
(11 \%)\end{array}$ & $11 / 86(13 \%)$ & 0.772 \\
\hline & no $(n=691)$ & $\begin{array}{l}23 / 443 \\
(5 \%)\end{array}$ & $14 / 248(6 \%)$ & 0.244 \\
\hline & $\begin{array}{l}\text { combined } \\
(n=935)\end{array}$ & $\begin{array}{l}40 / 601 \\
(7 \%)\end{array}$ & $25 / 334(7 \%)$ & 0.219 \\
\hline \multirow[t]{2}{*}{ MetS } & yes $(n=249)$ & $\begin{array}{l}27 / 186 \\
(15 \%)\end{array}$ & $1 / 63(2 \%)$ & 0.013 \\
\hline & no $(n=709)$ & $\begin{array}{l}15 / 164 \\
(9 \%)\end{array}$ & $22 / 545(4 \%)$ & 0.004 \\
\hline
\end{tabular}




\begin{tabular}{|l|l|l|l|l|}
\hline & $\begin{array}{l}\text { combined } \\
(\mathrm{n}=958)\end{array}$ & $\begin{array}{l}42 / 350 \\
(12 \%)\end{array}$ & $23 / 608(4 \%)$ & $<0.001$ \\
\hline
\end{tabular}

Supplementary Table 4. CVD mortality by the presence or absence of PNPLA3 rs738409, TM6SF2 rs58542926, MBOAT7 rs641738 or MetS. The statistical significance of differences was measured using Chi-Square test. Abbreviations: CVD, Cardiovascular Disease; MetS, Metabolic Syndrome. 